\title{
Co-composting Versus Direct Ponding of Sewage Sludge on Soil Nutrients Redistribution
}

\author{
Balaganesh P, Vasudevan M, Suneethkumar SM, Natarajan N
}

\begin{abstract}
Depriving soil fertility serves as one major cause for reduced crop growth rate and production, which in turn affects the food productivity. Various soil conservation measures to sequester the soil nutrients are adopted in developing countries locally and conventionally. In another scenario, present day sewage treatment plants (STP) across the nation are struggling to treat the receiving water quantity effectively. The fluctuations in receiving quantity of waste water resulted in untreated excess sludge dumping in nearby places. In order to synergize the excess sludge dumping in a feasible way by land management practices, the present study aims to compare two methods of sludge incorporating into soil, namely co-composting and direct ponding. Samples were collected from two different plots receiving sludge for different duration (fresh and old) at different depths $(12 \mathrm{~cm}, 24 \mathrm{~cm}$ and $36 \mathrm{~cm})$ and analyzed for various physicochemical parameters. The study also highlights the co-composting of sewage sludge with other community wastes to contribute a better analogy on nutrient redistribution. The obtained results of $17.34 \mathrm{mg} / \mathrm{l}$ total organic carbon and $1.392 \mathrm{mg} / \mathrm{l}$ total nitrogen at $36 \mathrm{~cm}$ depth in old sludge ponding sites reveals the improved capability of sludge leachate against the soil nutrient attenuation. It finds application in agricultural practice to promote crop growth under controlled conditions of sewage sludge amendment as ponding and co-composting.
\end{abstract}

Keywords-Agriculture, Co-composting, Land Management, Nutrient recycling, Sewage Sludge, Soil Organic Matter.

\section{INTRODUCTION}

The conventional and intensive agricultural methods cause soil fertility degradation, erosion and soil compaction, in addition to polluting surface waters [1][2]. The prevalence of soil nutrients in the agricultural field depends largely on the cultivation practices and effective management of agricultural residues. Soil conservation measures using agricultural residues have proven to be effective in restoring soil quality, rather improving productivity [3]. However, there is an increasing demand for sustainable waste management from agricultural as well as domestic origin, which seeks an intriguing opportunity to be settled as a favorable solution for multi-faceted problems with waste management.

Revised Manuscript Received on December 05, 2019.

* Correspondence Author

Balaganesh $\mathbf{P} *$, Civil Engineering, Bannari Amman Institute of Technology, Sathyamangalam, India. Email: balachem.aec@gmail.com

Vasudevan M, Civil Engineering, Bannari Amman Institute of Technology, Sathyamangalam, India. Email: vasudevan@ bitsathy.ac.in

Suneethkumar SM, Civil Engineering, Bannari Amman Institute of Technology, Sathyamangalam, India.

Email: suneethkumarsm@bitsathy.ac.in

Natarajan N, Civil Engineering, Dr.Mahalingam College of Engineering, Pollachi, India. Email: itsrajan2002@yahoo.co.in
Co-composting using municipal and agricultural waste materials promises safe, economic and eco-friendly solution for bringing out organic fertilizers as part of resource recovery [4]. The suitability and efficiency of co-composting system to minimize waste handling problems in a community depends primarily of the selection of co-substrates and prevailing environmental conditions [5]. Trupiano et al. [6] studied the impact of biochar and different combinations of co-compost on low fertile soil and reported that even though biochar itself have the potential to enhance soil nutrients, co-composting is recommended as a suitable technique to sustain the chemical characteristics of soil. In any case, incorporating compost in soil seems to improve soil nutrient redistribution and crop productivity [7][8].

In general, small scale community-based wastewater treatment plants in India experience overloading pressure of handling excess inflow as well as limited scope for infrastructural development [9]. In most of the cases, they are tempted to dispose the excess inflow to the nearby land either as untreated, or as mixed with partially treated water. This type of direct ponding has resulted in a considerably marsh-type land with very high organic contents which resembles eutrophication in wetland system. It is imperative that these organic-rich soils can be productive if employed effectively. This can be understood by few direct sewage sludge application studies. Melo et al. [10] studied about the 10 years direct application of sewage sludge in tropical climatic conditions and compared with mineral fertilization. Their experimental evaluation resulted in better biogeochemical properties by sewage sludge application rather than mineral fertilization, conversely there is no systematic approach available for such an attempt so far. Kayikcioglu and Abreu [11][12] reported that sewage sludge application on low fertile soil is the best sustainable agricultural practice to economically improve the soil fertility (Soil organic matter, Phosphorous, Nitrogen) but the potential toxic elements increases in the soil and may pose threat with respect to the amount of sewage sludge addition. In this study, we attempt to verify changes in soil nutrients distribution during various sludge application methods such as direct ponding, as well as reuse as an active ingredient in co-composting. We further attempts to investigate the potential impact of altering nutrient ratios of co-composting on land development options.

\section{MATERIALS AND METHODS}

\section{A. Study Area}

The STP with a capacity 7.5 MLD (million liters per day) located in the residential campus of Bannari Amman Institute of Technology, 
Sathyamangalam (Latitude 11.49520 and Longitude 77.27640), Tamil Nadu, India is running over capacity due to the up-surged inflow and lack of subsequent infrastructural development activities. As a temporary solution, the excess sludge has been diverted and stored in a low lying field of 103 $\mathrm{m}^{2}$ area in the close vicinity of the plant (old sludge ponding site). Over the years of practice, it has clearly deformed the soil structure and it resembles a marshy wetland soil. To comprehend the variation in nutrient dynamics, another low lying field in the STP chosen to dump fresh sludge (fresh sludge ponding). To analyze leachate attribute of the excess sludge on soil morphology in two different ponding sites (old sludge ponding and fresh sludge ponding), soil samples were regularly collected from the respective fields at different depths of $12 \mathrm{~cm}, 24 \mathrm{~cm}$ and $36 \mathrm{~cm}$ during the study period (July 2018to Jan 2019).

\section{B. Co-compost Preparation}

The domestic wastes generated within the campus premises were classified into RD-readily degradable (vegetable and food wastes), SD-slow-degradable (paper, green leaves, and cardboard), and PD - partially degradable (wood chips and dry leaves). The RD, SD and PD types of community wastes and Bulking agents (biochar prepared from bagasse, cardboard, paper) (Fig. 1.) were fed into the non-corrosive sheet-metallic bins to prepare in-vessel aerobic co-composts. The organic contents were mixed thoroughly once a week and moisture content and temperature were daily monitored. The bins were monitored for a period of 40 days and samples were taken regularly for evaluating the stability of sewage sludge amended co-compost in terms of various physico-chemical parameters.

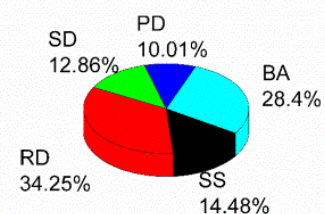

(a)

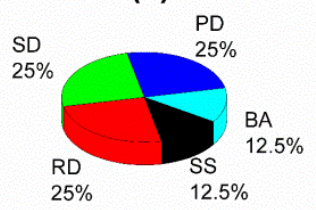

(c)

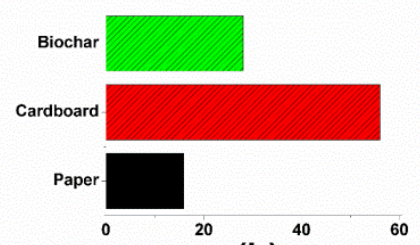

(b)

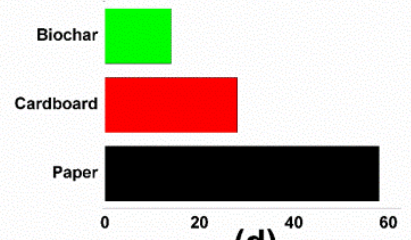

(d)
Fig. 1. Relative nutrient composition for different proportions of sewage sludge with co-substrates. (a) and (c) represents overall weight-based composition in two sets of composts. (b) and (d) represents volumetric proportion of bulking agents in two sets of composts

\section{Experimental Setup and Investigation}

Lab scale acrylic cylindrical column fabricated to simulate the co-compost impact on soil. Two columns were filled with soil and compost (25\% and $50 \%$ respectively). The column flushed with double distilled water continuously using peristaltic pump at controlled flow rate and leachate collected from the bottom of column. The collected leachate sample (5 $\mathrm{ml}$ ) from column with respect to time ( 5 minute interval) analysed along with soil and compost samples. The Soil and compost samples were taken periodically to assess physico-chemical parameters. Each 5 gram of sample were extracted and measured (as prescribed by Vasudevan et al.) [13] for $\mathrm{pH}$, Electrical Conductivity (EC), Nitrate Nitrogen, Chloride, Total Organic Carbon (TOC) and Total Nitrogen (TN).

\section{RESULT AND DISCUSSION}

\section{A. Soil nutrient dynamics with respect to depth}

The various forms of nitrogen (nitrate, nitrite and ammonium) present in soil decreasing with respect to increase in depths $(12 \mathrm{~cm}, 24 \mathrm{~cm}$ and $36 \mathrm{~cm}$ ) in both site (fresh sludge ponding and old sludge ponding site) (Table I, Table II). However, the concentration of total nitrogen (TN) was observed to be increasing slightly. This result reveals that the quantity of organic nitrogen quite increasing with respect to increase in depth. Nitrate $\left(\mathrm{NO}_{3}\right)$ varying from $101.89 \mathrm{mg} / \mathrm{l}$ to $50.2017 \mathrm{mg} / \mathrm{l}$ in fresh sludge ponding site soil. At the same time the $\mathrm{NO}_{3}$ value decreasing from $106.32 \mathrm{mg} / \mathrm{l}$ to 64.973 $\mathrm{mg} / \mathrm{l}$ in old sludge ponding site. The prolonged leaching attribute of old sludge ponding site resulted in high $\mathrm{NO}_{3}$ values compared to fresh sludge ponding site. It was observed in old sludge ponding site soil, that very least $\mathrm{NO}_{3}$ variation between $12 \mathrm{~cm}$ and $24 \mathrm{~cm}$ depth which is $106.32 \mathrm{mg} / \mathrm{l}$ and $100.413 \mathrm{mg} / \mathrm{l}$ respectively. There was no similar observation in fresh sludge ponding site soil. This is due to long lasting practice of sludge ponding in the soil which in turn resulted with enriched $\mathrm{NO}_{3}$ value. Generally speaking, the nitrite $\left(\mathrm{NO}_{2}\right)$ is not stable to predict, still the $\mathrm{NO}_{2}$ observed in both sites in less quantity. It was observed that $\mathrm{NO}_{2}$ decreasing with respect to depth from $14.67 \mathrm{mg} / \mathrm{l}$ to $5.5 \mathrm{mg} / \mathrm{l}$ in fresh sludge ponding site soil, whereas in old sludge ponding site soil decreasing from $25.5 \mathrm{mg} / \mathrm{l}$ to $2.5 \mathrm{mg} / \mathrm{l}$. The ammonium $\left(\mathrm{NH}_{4}\right)$ nitrogen resulted in very less quantity compared to others, which was from $0.1 \mathrm{mg} / \mathrm{l}$ to $0.026 \mathrm{mg} / \mathrm{l}$ and $0.293 \mathrm{mg} / \mathrm{l}$ to $0.01 \mathrm{mg} / \mathrm{l}$ respectively in fresh sludge and old sludge ponding sites. There was no variation observed in chloride content of soil samples with respect to depth in old sludge ponding site $(283.6 \mathrm{mg} / \mathrm{l})$. However, the chloride content slightly increasing in fresh sludge ponding site from 283.6 $\mathrm{mg} / \mathrm{l}$ to $285.6 \mathrm{mg} / \mathrm{l}$. Total organic carbon (TOC) values resulted in increasing trend with respect to increase in depth. In fresh sludge ponding site, TOC increased from $8.08 \mathrm{mg} / \mathrm{l}$ to $13.76 \mathrm{mg} / \mathrm{l}$ and from $8.515 \mathrm{mg} / \mathrm{l}$ to $17.34 \mathrm{mg} / \mathrm{l}$ in old sludge ponding site. Based on the TOC result it was understood that the organic matter is sufficiently rich in old sludge ponding site. When the TOC and TN values were increasing obviously $\mathrm{C} / \mathrm{N}$ values were also increased. $\mathrm{C} / \mathrm{N}$ values increased from 11.57 to 14.62 and 9.49 to 12.46 in fresh and old sludge ponding site soil. The electrical conductivity (EC) decreasing from $53 \mu \mathrm{S} / \mathrm{cm}$ to $30 \mu \mathrm{S} / \mathrm{cm}$ and $61 \mu \mathrm{S} / \mathrm{cm}$ to $55 \mu \mathrm{S} / \mathrm{cm}$ in fresh and old sludge ponding soil respectively. The reduction in EC with respect to depth reveals that the ionic particles (salt) rich in the top soil and leaches gradually from top to the bottom soil.

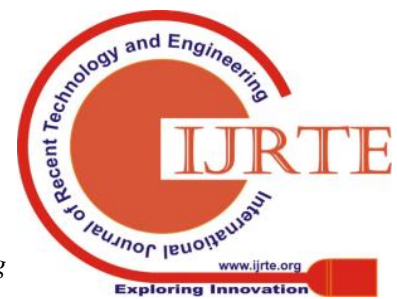


Table- I: Chemical composition of soil sample collected from fresh sludge ponding site

\begin{tabular}{|c|c|c|c|c|c|c|c|c|}
\hline \multirow[b]{2}{*}{$\begin{array}{c}\text { Samp } \\
\text { le } \\
\text { depth } \\
\text { (cm) }\end{array}$} & \multicolumn{8}{|c|}{ Physico-chemical parameters } \\
\hline & $\begin{array}{l}\mathrm{NO}_{3} \\
(\mathrm{mg} / \\
\mathrm{L})\end{array}$ & $\begin{array}{l}\mathrm{NO}_{2} \\
(\mathrm{mg} / \\
\mathrm{L})\end{array}$ & $\begin{array}{l}\mathrm{NH}_{4} \\
(\mathrm{mg} / \\
\mathrm{L})\end{array}$ & $\begin{array}{l}\text { Chlori } \\
\text { de } \\
\text { (mg/L } \\
)^{2}\end{array}$ & $\begin{array}{l}T O \\
C \\
(m \\
g / L\end{array}$ & $\begin{array}{l}T N \\
(m g / \\
L)\end{array}$ & $\begin{array}{l}\text { TOC } \\
/ T N\end{array}$ & $\begin{array}{l}E C \\
(\mu S \\
/ c m \\
)\end{array}$ \\
\hline 12 & $\begin{array}{c}101 . \\
89\end{array}$ & $\begin{array}{c}14.6 \\
7\end{array}$ & 0.11 & $\begin{array}{c}283.6 \\
0\end{array}$ & $\begin{array}{c}8.0 \\
8\end{array}$ & 0.69 & $\begin{array}{c}11.5 \\
7\end{array}$ & $\begin{array}{c}53 . \\
00\end{array}$ \\
\hline 24 & $\begin{array}{c}67.9 \\
3\end{array}$ & 9.83 & 0.07 & $\begin{array}{c}284.6 \\
0\end{array}$ & $\begin{array}{l}10 . \\
46\end{array}$ & 0.81 & $\begin{array}{c}12.8 \\
6\end{array}$ & $\begin{array}{r}45 . \\
00\end{array}$ \\
\hline 36 & $\begin{array}{c}50.2 \\
1\end{array}$ & 5.50 & 0.03 & $\begin{array}{c}285.6 \\
0\end{array}$ & $\begin{array}{l}13 . \\
76\end{array}$ & 0.94 & $\begin{array}{c}14.6 \\
2\end{array}$ & $\begin{array}{c}30 . \\
00\end{array}$ \\
\hline
\end{tabular}

Table- II: Chemical composition of soil sample collected from old sludge ponding site

\begin{tabular}{|c|c|c|c|c|c|c|c|c|}
\hline \multirow[b]{2}{*}{$\begin{array}{c}\text { Samp } \\
\text { le } \\
\text { depth } \\
(\mathrm{cm})\end{array}$} & \multicolumn{8}{|c|}{ Physico-chemical parameters } \\
\hline & $\begin{array}{l}\mathrm{NO}_{3} \\
(\mathrm{mg} / \\
\mathrm{L})\end{array}$ & $\begin{array}{l}\mathrm{NO}_{2} \\
(\mathrm{mg} / \\
\mathrm{L})\end{array}$ & $\begin{array}{l}\mathrm{NH}_{4} \\
(\mathrm{mg} / \\
\mathrm{L})\end{array}$ & $\begin{array}{l}\text { Chlori } \\
\text { de } \\
(\mathrm{mg} / \mathrm{L} \\
)\end{array}$ & $\begin{array}{l}T O \\
C \\
(m \\
g / L \\
)\end{array}$ & $\begin{array}{l}T N \\
(m g / \\
L)\end{array}$ & $\begin{array}{l}\text { TOC } \\
/ T N\end{array}$ & $\begin{array}{l}E C \\
(\mu S \\
/ c m \\
)\end{array}$ \\
\hline 12 & $\begin{array}{l}106 . \\
32\end{array}$ & 25.5 & 0.29 & $\begin{array}{l}283.6 \\
0\end{array}$ & $\begin{array}{l}8.5 \\
2\end{array}$ & 0.89 & 9.49 & $\begin{array}{l}61 . \\
00\end{array}$ \\
\hline 24 & $\begin{array}{l}100 . \\
41\end{array}$ & $\begin{array}{l}21.3 \\
3 \\
\end{array}$ & 0.24 & $\begin{array}{l}283.6 \\
0 \\
\end{array}$ & $\begin{array}{l}12 . \\
66\end{array}$ & 1.09 & $\begin{array}{l}11.6 \\
6 \\
\end{array}$ & $\begin{array}{l}60 . \\
00\end{array}$ \\
\hline 36 & $\begin{array}{c}64.9 \\
7\end{array}$ & 2.50 & 0.01 & $\begin{array}{c}283.6 \\
0\end{array}$ & $\begin{array}{l}17 . \\
34\end{array}$ & 1.39 & $\begin{array}{c}12.4 \\
7\end{array}$ & $\begin{array}{l}55 . \\
00\end{array}$ \\
\hline
\end{tabular}

\section{B. Impact of direct ponding on land with time}

The observed $\mathrm{pH}$ values in both sites (site\#1-fresh sludge ponding and site\#2-old sludge ponding) were in the range of 6.3 to 8.3 which is slight acidic to slight basic (Fig. 2). The $\mathrm{pH}$ of site\# 1 initially decreased in the month of July but later increased and again followed the fluctuated trend, similar fluctuated trend observed in site\#2. In the present study, the co-compost derived from sewage sludge and biochar as one of the bulking agent. So the fluctuations can be understood as per the previous author's report Florentino et al. [14], that direct application of sewage sludge on soil resulted in reduced $\mathrm{pH}$ due to proton release during decomposition. Conversely, Figueiredo [15] reported that pyrolysis of sewage sludge (biochar) can increase $\mathrm{pH}$ of the soil. The EC values of site\#1 initially fluctuated and later gradually decreased in January 2019, whereas in site\#2 EC slightly increased in July and after mid-October fluctuated. The Moisture content of (MC) of both site soils almost followed similar uneven trend with respect to time. The result of MC closely related to the prevailing climatic conditions during July 2018 to January 2019. TOC of both sites decreased during July to October and again gradually increased till January 2019. There is not much variations observed in $\mathrm{TN}$ with respect to time in both sites. It reveals that TN stabilized by the sludge amendment.

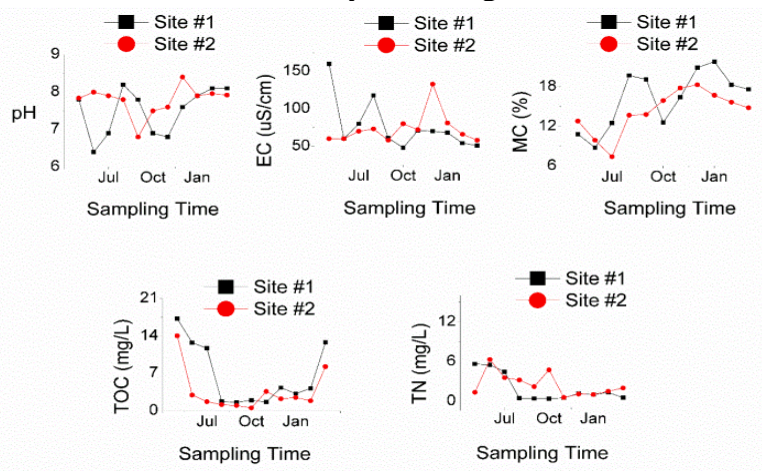

Fig. 2. Seasonal variation in physico chemical properties of sludge-ponded soil samples

\section{Impact of compost application in soil}

The nitrate constituent is one of the key elements for the plant growth and thus, the leachate collected from column analyzed for its concentration. Within few minutes of leachate infiltration the nitrate values observed more than $12 \mathrm{mg} / \mathrm{l}$ in both $25 \%$ and $50 \%$ compost amended soil. The result follows the breakthrough curve in the form of gradual increase in concentration up to the peak and then decreased gradually with respect to time (Fig. 3).

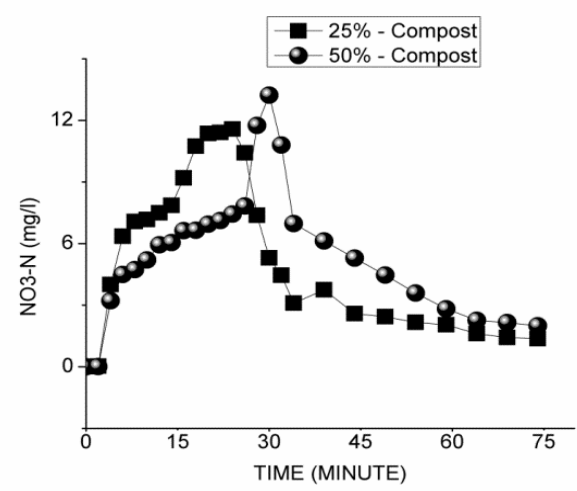

Fig. 3. Variation in nitrate concentration in sewage sludge co-compost amended soil column

\section{CONCLUSION}

In general, sewage sludge application on low fertile soil is the best sustainable agricultural practice to economically improve the soil fertility (Soil organic matter, Phosphorous, Nitrogen). However the potential toxic elements increases in the soil and may pose threat with respect to the amount of sewage sludge addition [11][12]. The present study concludes that the direct ponding of sewage sludge from STP in both sites (fresh and old ponding) resulted in improved soil nutrient redistribution, on the other hand co-composting of sewage sludge under controlled conditions yields better for soil nutrient attenuation rather than direct ponding methods. This can be understood by the lab scale column study where the leachate can provide nutrients (nitrate) within few hours of infiltration. It finds application in agricultural practice to promote crop growth under controlled conditions of sewage sludge amendment in the form of co-compost.

\section{ACKNOWLEDGMENT}

The authors wish to acknowledge DST-SERB, Govt. of India [ECR/2016/001114/ES] for their funding and support rendered by the Bannari Amman Institute of Technology, Sathyamangalam.

\section{REFERENCES}

1. G X. Kong, F. Zhang, Q. Wei,Y. Xu, J. Hui, "Influence of land use change on soil nutrients in an intensive agricultural region of North China," Soil and Tillage Res., vol. 88(1-2), pp. 85-94, July 2006

2. Y. Liu, Z. Yu, J. Chen,F. Zhang, R. Doluschitz,JC. Axmacher, "Changes of soil organic carbon in an intensively cultivated agricultural region: A denitrification-decomposition (DNDC) modelling approach," Sci. of the tot. env., vol. 372(1), pp. 203-14, December 2006 
3. R. Rasool, SS. Kukal, GS. Hira, "Soil physical fertility and crop performance as affected by long term application of FYM and inorganic fertilizers in rice-wheat system," Soil and Tillage Res., vol. 96(1-2), pp. 64-72, October 2007

4. L. Zhang, X. Sun, "Changes in physical, chemical, and microbiological properties during the two-stage co-composting of green waste with spent mushroom compost and biochar," Biores. tech., vol. 171, pp. 274-84, November 2014

5. R. Scotti, C. Pane, R. Spaccini, AM. Palese, A. Piccolo, G. Celano, M. Zaccardelli, "On-farm compost: a useful tool to improve soil quality under intensive farming systems," Applied Soil Ecol., vol. 107, pp. 13-23, November 2016

6. D. Trupiano, C. Cocozza, S. Baronti, C. Amendola, FP. Vaccari, G. Lustrato, S. Di Lonardo, F. Fantasma, R. Tognetti, GS. Scippa, "The effects of biochar and its combination with compost on lettuce (Lactuca sativa L.) growth, soil properties, and soil microbial activity and abundance, Inter. J. of Agronomy, 2017

7. A. Lakhdar, M. Rabhi, T. Ghnaya, F. Montemurro, N. Jedidi, C. Abdelly, "Effectiveness of compost use in salt-affected soil," J. of haz. mat., vol. 171(1-3), pp. 29-37, November 2009

8. R. Scotti, G. Bonanomi, R. Scelza, A. Zoina, MA. Rao, "Organic amendments as sustainable tool to recovery fertility in intensive agricultural systems," J. of soil sci. and plant nutrit., vol. 15(2), pp. 333-52, June 2015

9. N. Shiota, A. Akashi, S. Hasegawa, "A strategy in wastewater treatment process for significant reduction of excess sludge production," Water sci. and technol., vol. 45(12), pp. 127-34, 2002 Jun 1; June 2002

10. W. Melo, D. Delarica, A. Guedes, L. Lavezzo, R. Donha, A. de Araújo, G. de Melo, F. Macedo, "Ten years of application of sewage sludge on tropical soil. A balance sheet on agricultural crops and environmental quality," Sci. of the tot. env., vol. 643, pp. 1493-501, December 2018

11. HH. Kayikcioglu, H. Yener, AR. Ongun, B. Okur," Evaluation of soil and plant health associated with successive three-year sewage sludge field applications under semi-arid biodegradation condition," Arch of Agron. and Soil Sci., vol. 10, pp. 1-8, February 2019

12. CH. Abreu-Junior, MJ. de Lima Brossi, RT. Monteiro, PH. Cardoso, T. da Silva Mandu, TA. Nogueira, A. Ganga, P. Filzmoser, FC. de Oliveira, LP. Firme, Z. He, "Effects of sewage sludge application on unfertile tropical soils evaluated by multiple approaches: A field experiment in a commercial Eucalyptus plantation," Sci. of the tot. Env., vol. 655, pp. 1457-67, March 2019

13. M. Vasudevan, K. Karthika, S. Gowthaman, K. Karthick, P. Balaganesh, SM. Suneeeth Kumar, N. Natarajan, "Aerobic in-vessel co-composting of dewatered sewage sludge with mixed municipal wastes under subhumid and semiarid atmospheric conditions," Energy Sources, Part A: Rec., Util., and Env. Effects, pp. 1-12, June 2019

14. AL. Florentino, A. de Vicente Ferraz, JL. de Moraes Gonçalves, V. Asensio, T. Muraoka, CT. dos Santos Dias, TA. Nogueira, GF. Capra, $\mathrm{CH}$. Abreu-Junior, "Long-term effects of residual sewage sludge application in tropical soils under Eucalyptus plantations," J. of Clean. Produc., vol. 220, pp. 177-87, May 2019

15. CC. de Figueiredo, WM. Farias, TR. Coser, AM. de Paula, MR. da Silva, J. Paz-Ferreiro, "Sewage sludge biochar alters root colonization of mycorrhizal fungi in a soil cultivated with corn," Eur. J. of Soil Biol., vol. 93, 103092, July 2019

\section{AUTHORS PROFILE}

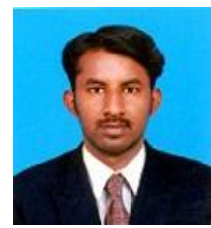

Balaganesh $\mathbf{P}$ is working as a Research Scholar in the Department of Civil Engineering at Bannari Amman Institute of Technology Sathyamangalam, Tamil Nadu, India. He obtained M.E. in Environmental Engineering from Anna University affiliated institution, M.A.M. College of Engineering, Trichy, Tamilnadu, India. His areas of interest include solid waste management, wastewater treatment and bioenergy conversion.

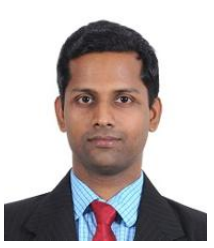

Vasudevan $\mathbf{M}$ is working as Assistant Professor in the Department of Civil Engineering at Bannari Amman Institute of Technology Sathyamangalam, Tamil Nadu, India. $\mathrm{He}$ obtained $\mathrm{PhD}$ in Environmental (Civil) Engineering from Indian Institute of Technology Madras in 2015. He works in the area of sustainable waste management, clean technology, groundwater contamination assessment and modeling.

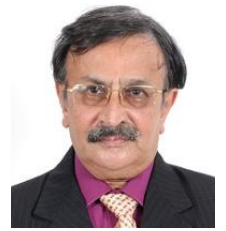

Suneethkumar SM is working as Professor in the Department of Civil Engineering at Bannari Amman Institute of Technology Sathyamangalam, Tamil Nadu, India. He obtained $\mathrm{PhD}$ in Environmental (Chemical) Engineering from Indian Institute of Technology Kanpur in 1998. His areas of interest include environmental engineering and water supply and infrastructure.

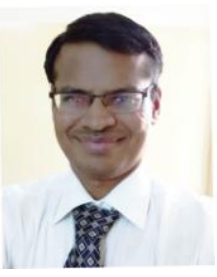

Natarajan $\mathbf{N}$ is working as Associate Professor in the Department of Civil Engineering at Dr. Mahalingam College of Engineering and Technology, Pollachi, Tamil Nadu, India. He obtained PhD in Water Resources (Civil) Engineering from Indian Institute of Technology Madras in 2012. We work in the area of environmental modeling and assessment, clean technology, groundwater contamination assessment and modeling. 